\title{
Hang Him High: The Elevation of Jánošík to an Ethnic Icon
}

\author{
Martin Votruba
}

\author{
Slavic Review 65\# 1: 24-44.
}

Academic research into the West Slavic living legend of Jánošík has largely accepted that his contemporary myth is an outgrowth of his veneration as a valiant rebel against oppression in traditional folk culture. ${ }^{1}$ The myth of the ubiquity of folk songs about Jánošík has crossed the confines of Central European academe. ${ }^{2}$ The myth of his heroic revolt against feudal tyranny materialized in English popular fiction. ${ }^{3}$ The actual historical figure Juraj Jánošik, a 25-year old brigand band leader from Terchová in the north-western County of Trenčin, was hanged at Liptovský Mikuláš, ${ }^{4}$ the seat of Liptov County, on 17 March 1713. For barely more than one robbing season, ${ }^{5}$ he ambushed

${ }^{1}$ The major proponent of Jánošík's myth under Communism became Andrej Melicherčík, Jánošíkovská tradícia na Slovensku (Bratislava: Nakladatel'stvo Slovenskej akadémie vied a umení, 1952). His subsequent publications, as well as those by dozens of other authors followed his lead. It still resonates, for example, in the views of Dušan Škvarna, Začiatky moderných slovenských symbolov: K vytváraniu národnej identity od konca 18. do polovice 19. storočia (Banská Bystrica: Univerzita Mateja Bela, Fakulta humanitných vied, 2004). A well argued major break with that legacy came from Joanna Goszczyńska, Mit Janosika w Folklorze i Literaturze Stowackiej XIX Wieku (Warszawa [Warsaw]: Uniwersytet Warszawski, Instytut Filologii Słowiańskiej, 2001).

2 "literally hundreds of songs about him [Jánošík] survive to the present day," Eric Hobsbawm, Bandits (New York: Delacorte Press, 1969): 47.

${ }^{3}$ Similar comments occur in several English novels, for example, "Jánošík, the Slovak outlaw hero, who took to the hills $[\ldots]$ in revolt against the feudal tyranny that kept his countrymen serfs." Ellis Peters [Edith Pargeter], The Piper on the Mountain (New York: William Morrow \& Company, Inc., 1966): 70. (There are several reissues, most recently in 1996.)

${ }^{4}$ To aid orientation and simplify the references to the localities in the Carpathians, their diverse historical spellings have been standardized in the body of this paper to those identifiable on modern maps of Central Europe. The modern names are distinctly anachronistic only in the case of Bratislava, named so in 1919, whose earlier names were Prešporok (Slovak), Pressburg (German), Istropolis/Posonium (Latin), Pozsony (Hungarian). The bibliographical references give the spellings of the places of publication from the title pages followed by their customary English or modern local names in brackets.

${ }^{5}$ Due to inclement weather (moreover during Europe's Little Ice Age, 1560-1850), a decrease in travelers, and the winter closures of high-elevation sheep folds, where shepherds sometimes sold the brigands food, bought their loot for resale or passed on intelligence about police searches, brigand bands in the Western 
travelers in the northern and central predominantly Slovak counties in the Habsburg monarchy. Details of his life come from scanty sources and even those were generally unknown and therefore not relevant for his image until the early $19^{\text {th }}$ century. ${ }^{6}$ The proceedings from his trial show that, although Jánošík was held responsible as the band leader, the court accepted that a member of his band, rather than Jánošik himself, had probably shot a priest, who died a month later. Except for that charge, he was not convicted of murdering any of those he robbed, but that did not enter public awareness until almost a hundred years later. The earliest recorded song about Jánošík speaks of him as a killer. Once a synopsis of his trial was printed, the absence of charges of murder marked a key moment in the development of his specific image. His preserved earlier images were not specific of the historical character, nor were they consistent. They were largely interchangeable with those of other brigands.

The preselection of Jánošík as a future heroic, tragic rebel of high literature took place before the emergence of the Romanticized images of outlaws as they were shaped in the 1810s and 1820s by authors at the remote perimeters of Western and Eastern Europe like Lord Byron in London (and Greece) and Aleksandr Pushkin in St. Petersburg (and the Caucasus). Like in London, the early literary outlaw model that circulated in the Western Carpathians after 1781 was that of the main character in The Robbers by Friedrich Schiller, ${ }^{7}$ who became professor of history at the University of Jena in Saxony, the alma mater of many Slovak intellectuals at that time. Some took Schiller's courses and all witnessed the already fervent German ethnic activism. The scant other models available in the early decades of the $19^{\text {th }}$ century were first largely channeled back to Central Europe through German culture. ${ }^{8}$ The interaction became more multicultural later. For instance, occasional classes on Slavic literatures were taught at the Lutheran junior college in Bratislava in the 1830s and 1840s (practically all the Slovak writers of the $19^{\text {th }}$ century were Lutherans). Almost two decades after Pushkin appeared in German, the first translation of his poetry, albeit without an outlaw, was published in a Slovak literary journal in 1838. The German proto-Romantic model of a doomed mutineering brigand was reflected in a Czech tragic love poem with an ethnically rous-

Carpathians would traditionally disperse on or not long after Michaelmas (29 September) and agree to reassemble on St. Adalbert's Feast-Georgemas (23-24 April).

${ }^{6}$ The most recent reconstruction, with some confused geography and details, is by Stanisław A. Sroka, $J a-$ nosik - prawdziwa historia karpackiego zbójnika (Kraków [Cracow]: Wydawnictwo Homini, 2004): 29-60; and Stanisław Dzięciołowski, the author of several papers on Jánošík, has announced his forthcoming reconstruction Juraj Janosik hetman zbójnicki.

${ }^{7}$ Anon. [Friedrich Schiller], Die Räuber. Ein Schauspiel (Stuttgart: [s.n.], 1781). A revised version before its Mannheim premiere: Die Räuber. Ein Trauerspiel (Frankfurt und Leipzig: bei Tobias Löffler, 1782). (There are numerous reeditions and translations.)

${ }^{8}$ The geographic and cultural distance worked both ways: when imitations of South Slavic poems from Dalmatia, Bosnia, and Herzegovina caught Alexandr Pushkin's interest in 1834, he translated them and called them "Songs of the Western Slavs" (Песни западных славян). 
ing dedication in the 1830s. Byron's works became available in Polish in the 1830s and in Hungarian in the 1840 s. None of that was in place early in the $19^{\text {th }}$ century.

It might appear unsurprising today that Jánošík's legend spread out, although not in the same form, in the Slovak, Czech and Polish cultures and that he is still remembered. He is the local embodiment of the pervasive myth of a hero who takes from the rich and gives to the poor, and he had other quite universally idolized trappings, the ones that, for example, helped to generate Hollywood's legendary rebel stars - he was good looking, single, made a stash of money, lived wild, and died young. "Our salvation can come only from Jánošík," laments a Czech blogger over the budget proposals in Prague in the $21^{\text {st }}$ century. ${ }^{9}$ In Poland, a group of developers has been working on software intended to break the monopoly of the program called Płatnik ("Payer"), which is mandatory for employers and works only with Microsoft Windows. The leader of the developers named their open-source software Janosik. ${ }^{10}$ The Jánošík of modern high culture has a firm place in the mosaic of the Slovaks' perceptions of their past. He is the noble, tragic rebel who rose against the material oppression of the feudal overlords, and by implication, also against the ethnic oppression of the Slovaks by the Hungarians as well as against social and political inequalities. ${ }^{11}$ The Romantic poem The Death of Jánošik by Ján Botto is considered one of the high points of literature. ${ }^{12}$ This and other cultural images of Jánošík are seen as a faithful sublimation of the hero of traditional folk songs and tales. The standardized nation-wide curriculum interprets it cyclically in grade school, in middle school, and again in high school. Because his modern image is said to have stemmed from historical folk culture, his insubordination represents what the Slovaks' discontented ancestors wished they could emulate, but were not able to. ${ }^{13}$ He was a martyr of righteous social and ethnic resistance.

Yet, although the attributes of good looks, money, and a romantic early death helped Jánošík to achieve an iconic status to be both cherished and lampooned in Slovak culture today, this is not how he became famous. It took almost a century after Jánošík was hanged for his myth to make the first inroads into high culture, and then it took an implicit literary battle involving such eminent Slavic figures in the Habsburg

9 "Spasit nás může jen Jánošík." Hana Formánková, "Spravedlnosti zadost by mohl učinit jen Jánošík." 1 October 2003, at http://www.neraweb.cz/index.php?stype=all\&id=632.

${ }^{10}$ Danuta Frey, "Janosik chce rozgryźć program Płatnik," Rzeczpospolita 6-7 December 2004.

${ }^{11}$ Felicitas Maukšová, "Recepcia Bottovej Smrti Jánošíkovej v školskej praxi," in Július Bolfík, ed. Ján Botto - život a dielo (v Rimavskej Sobote [Rimavská Sobota]: Gemerská vlastivedná spoločnost', 1983): 93-100.

${ }^{12}$ In addition to being included in numerous anthologies, it has appeared in at least eleven single-poem editions. - Ján Botto, “Smrt' Jánošíka. Romanca," Lipa II (1862): 251-278. (Its final revision for the 1880 Prague edition was renamed, despite Botto's objections, to its current title "Smrt' Jánošíkova" by its coeditor Jaroslav Vlček on the advice of Prof. Martin Hattala from Charles University.)

${ }^{13}$ Patricia Ann Krafcik, "Jánošík, the Slovak Robin Hood: The Brigand Metes Out Justice" paper, $34^{\text {th }}$ National Convention, American Association for the Advancement of Slavic Studies, Pittsburgh, 21-24 November 2002; with a detailed analysis by discussant David Cooper, Columbia University. 


\section{Martin Votruba: Hang Him High: The Elevation of Jánošik to an Ethnic Icon}

monarchy as Pavol Jozef Šafárik and Ján Kollár to pigeonhole him in it. ${ }^{14}$ Juraj Jánošík died young, but he did not acquire treasures, become handsome and singularly famous until he was past 150. The entrance of Jánošik's image into high literature in the $19^{\text {th }}$ century signaled a substantial break with the earlier images of highway robbery in the Western Carpathian region. Although folk art was certainly an impetus and did provide the modern Jánošik with his costume, it did not give Jánošik his mission in high culture, as attested by three collections of traditional Slovak folk songs with over 1,000 of them categorized as brigand songs. ${ }^{15}$ The proponents of the modern myth evoke highly selective and interpretive readings of folk songs as evidence of its folk origin. ${ }^{16}$ Contrary to his position in the modern myth, the traditional songs are rarely a celebration of brigands as opposed to their depiction. With fewer than half a dozen exceptions, any celebration they contain concerns the brigands' taking from the rich and giving to the poor, or even more seldom, engaging in a payback to the ruthless landlords or authorities. Moreover, they do not contain a single ethnically-colored image of a rebel against Hungarian oppression.

\section{Medieval legend}

Although a good deal of highway robbery occurred long before Jánošík, no representation of it appeared in the high culture of the Slovak counties. Yet given the general human fascination with crime and the prevalence of highway robbery in European history, it is perhaps safe to assume that images of brigands had been part of the local folk culture for centuries. The earliest literary account of brigands in the Slovak Carpathians is in the Legend of Saints Zoerardus and Benedict written in Latin by Bishop Maurus around 1064. ${ }^{17}$ It contains little specific or unexpected information about brigands themselves - they congregated in lonely places, they had fights, they had empathy for their band members, they were killers, and they drowned a monk near the town of

${ }^{14}$ Also spelled Paul/Pavel Joseph/Josef Schaffarik/Šafařík, and Jan Kollár.

${ }^{15}$ Anon., “Zbojnícka l’udová poézia.” Rudo Brtáň, Viera Gašparíková, eds. Perečko belavé, červený dolomán (Praha: Naše vojsko, 1955): 39-122; Jiří Horák and Karel Plicka, eds. Zbojnícke piesne slovenského l’udu (Bratislava: SVKL, 1965); and Viera Gašparíková, ed. Jánošík, obraz zbojníka v národnej kultúre (Bratislava: Tatran, 1988).

${ }^{16}$ Martin Votruba, "The Death of the Heroically Chopped-up Shepherd: Highway Robbery in Slovak Literature and Lore." paper, $37^{\text {th }}$ National Convention, American Association for the Advancement of Slavic Studies, Salt Lake City, 3-6 November 2005.

${ }^{17}$ Maurus, Bishop of Quinque Ecclesiae $(\dagger 1070)$, "Vita sanctorum heremitarum Zoerardi confessioris et Benedicti martiris a beato Mauro episcopo Quinecclesiastensi [sic] descripta," Scriptores rerum Hungaricarum, tempore ducum regumque stirpis Arpadianae gestarum, vol. II, edited by Emericus Szentpétery (Budapest: Academia Litter. Hungarica atque Societae Histor. Hungarica, 1938): 357-361. (There are several editions and translations.) - Bishop Maurus's seat is now called Pécs in Hungary. He had the story from St. Hippolyte's Benedictine Monastery at Zobor near the town called Nitra in Slovakia. Zoerardus is rendered as Swierad in Polish, Svorad in Slovak, Zoerárd/Szórád in Hungarian; the legend identifies him as having come from Poland, wich extended over parts of today's Slovakia for several decades in the $11^{\text {th }}$ century. 
Trenčin. The passage does contain an aspect that recurred with brigand themes hundreds of years later. Although recorded by a bishop, this legend's account of brigands is not a moralistic tale designed to condemn the cutthroats. While it conveys no overt expression of sympathy for the murdered monk Benedict, it stages a miracle to save a criminal already hanging on the gallows, simply because he begged Saint Zoerardus to do so, and it transforms a brigand into a holy man.

\section{Early local motifs}

Another isolated, but this time fairly comprehensive and influential literary account of brigands in the Slovak counties appeared in German after about 600 years. ${ }^{18}$ It is generally accepted that The Hungarian Simplicissimus was written by Daniel Speer, a student of music from Silesia who spent about six years in Spiš and Šariš Counties in the 1650 s. Contrary to occasional assumptions, the author did not derive his images of brigandage from the proposed sources published around that time. As Speer's major, if not sole, source, the available circumstantial evidence points to images already present in the local popular culture as well as possible personal experiences embellished with those images.

Thus The Hungarian Simplicissimus did not derive the inspiration for any of its brigand stories, as has been suggested, ${ }^{19}$ from Theatrum Europæum, a chronicle of events that started covering Germany and to a lesser degree other Europe in 1617.20 In Theatrum Europæum, the sparse references to robberies merely mention, in three or four sentences at the most, events that took place, mainly in Italy. Rather than highway robberies, they note plunders of towns, and what we would today call "burglaries." They contain no descriptions of the perpetrators themselves and their lives.

${ }^{18}$ Dacianischer Simplicissimus [probably Daniel Speer], Ungarischer Oder Dacianischer SIMPLICISSIMUS, Vorstellend Seinen wunderlichen Lebens-Lauff Und Sonderliche Begebenheiten gethaner Räisen. Nebenst Wahrhaffter Beschreibung deß vormals im Flor gestandenen und öffters verunruhigten Ungerlands, So dann Dieser Ungarischen Nation Sitten, Gebräuch, Gewohnheiten und führenden Kriege. Sambt Deß Grafen Tekely Herkommen, und biß auf jetzige Zeit verloffenen Lebens-Lauff. Denck-würdig und lustig zu lesen ([s.1.]: Heraußgegeben von gedachtem Dacianischen Simplicissimo, edruckt im Jahr MDCLXXXIII). Facsimile (Konstanz [Constance]: Seeverlag, Anno MDCDXXII). (There are numerous reissues and translations.)

${ }^{19}$ József Turóczi-Trostler, "Német kalandorok Magyarországon, a 'Magyar Simplicissimus' és a 'Török kalandor' forrásai," Magyar figyelo", 23, 1913: 366-383; referenced by Jan Reychman, "Przedmowa," in Danuta Reychmanowa, trans., and Jan Reychman, ed., Węgierski bądź Dacki Simplicissimus, (Kraków [Cracow]: Wydawnictwo Literackie, 1967: 5-32; related by Goszczyńska Mit Janosika..., and by others.

${ }^{20}$ Johann Phillip Abelinus, et al. THEATRUM EUROPAUM. This is a series with multiple issues covering the period from 1618 to 1738 starting with volume 1: THEATRUM EUROPAEUM oder Außfuerliche und Warhafftige Beschreibung aller und jeder denckwierdiger Geschichten [...] vom Jahr Christi 1617. biß auff das Jahr 1629. exclus. [...] (Franckfurt am Mayn [Frankfurt am Main]: bey Daniel Fievet, Im Jahr nach Christi Geburt MDCLXII). Also available online at http://www.bibliothek.uniaugsburg.de/de/dda/dr/hist/werke/we_00001-00021/index.html 


\section{Martin Votruba: Hang Him High: The Elevation of Jánošik to an Ethnic Icon}

As its title suggests, Speer's book was clearly modeled on the earlier German Simplicissimus, a popular book of adventures by another author. ${ }^{21}$ Although The Hungarian Simplicissimus derives some of its themes from its German namesake, none of the accounts of brigands bear any resemblance to the robberies described in its German predecessor. Among the less significant differences, for example, The Hungarian Simplicissimus employs a landscape image quite unlike anything in the German Simplicissimus - that of a wild and improbably narrow ravine, a setting for brigand or rebel ambushes made famous all over Central Europe much later through the Romantic play William Tell. ${ }^{22}$ Such a ravine subsequently recurred in Slovak narratives about brigands, as well, and was used as a setting in films about Jánošík. ${ }^{23}$

More important, though, whereas all the instances of plunder in the German model were carried out by armies and displaced mercenaries, The Hungarian Simplicissimus portrays highway robberies as we expect them today. It speaks of brigandage arising from the local population, rooted in its villages. It also exposes some of the brigandage as likely extortion schemes rather than traditional highway robbery. In some villages in the Polish Podhale, travelers crossing the border to Spiš County through uninhabited forests were warned against highway robbery and advised to hire protective escort. After money was exchanged, sometimes a single man would trudge along, who apparently communicated with brigands and thus secured safe passage for the party of travelers. In addition to real ambushes by brigands, stories designed to frighten by such entrepreneurs certainly contributed images to the popular mythology of brigandage.

The Hungarian Simplicissimus either invented his accounts of brigands from scratch, or relied on unknown literary sources, or - quite likely - channeled and embellished images of brigands that were already present in popular culture of the Slovak counties in the $17^{\text {th }}$ century. ${ }^{24}$ In narratives, highway robberies are almost the sole exploits of the brigands, while the balance of real robberies by the bands in the region was heavily tilted toward crimes against farms. A collection of court records related to brigandage in the Polish Carpathians spanning the $17^{\text {th }}$ and $18^{\text {th }}$ centuries contains a pro-

${ }^{21}$ German Schleisheim von Sulsfort [Hans Jakob Christoffel von Grimmelshausen], Der Abentheuerliche SIMPLICISSIMUS Teusch - Das ist: Die Beschreibung deß Lebens eines seltzamen Vaganten - genannt Melchior Sternfels von Fuchshaim - wo und welcher gestalt Er nemlich in diese Welt kommen - was er darinn gesehen - gelernt - erfahren und außgestaden - auch warumb er solche wider freywillig quittirt. Überau $\beta$ lustig und männiglich nutzlich zu lesen (Monpelgart [Nuremberg]: Gedruckt bey Johann Fillion, Jm Jahr MDCLXIX). Facsimile (Tübingen: Max Niemeyer, 1954). (There are numerous reissues and translations.)

${ }^{22}$ Friedrich Schiller, "Vierter Aufzug - Der Tyrannenmord, Dritte Szene," Wilhelm Tell (Tübingen: In der F.G. Cotta'schen Buchhandlung, 1804). (There are numerous reissues and translations.)

${ }^{23}$ Jánošík directed by Jaroslav Jerry Siakel' (Tatra Film, Chicago, 1921); Jánošík directed by Martin Frič (A-B Studio, Praha [Prague], 1935); Jánošík I and II directed by Pal'o Bielik (Koliba, Bratislava, 1963).

${ }^{24}$ In reference to the Slovaks the author writes Slovaken oder Wenden, Slovakisch oder Wendisch, sometimes he uses just one, or the other word; he also spells the latter one as Windisch, and the former one once as Schlowacken. In reference to the Rusyns (Ruthenians) he says Rusnaken, Rusnakisch. 
fusion of such acts, but lists hardly any charges of highway robbery. ${ }^{25}$ Yet, it was the image of an ambush in the deep forest, or a raid not on a farm but on a remote mountain sheepfold, that captured popular imagination and became quintessential to the representation of brigandage in folk songs from the period. The likelihood is therefore high that in its representation of brigandage, The Hungarian Simplicissimus drew mostly on narratives already fictionalized and embedded in the local popular culture rather than on descriptive accounts of actual events overheard or experienced and inflated by the author.

When viewed in retrospect, The Hungarian Simplicissimus seems to foreshadow the real Jánošík when it notes that Liptov County had a particular reputation for highway robbery, for it was Liptov County that hanged Jánošík some sixty years later, not long after he made his biggest booty there. But the references to the "Bad Birds" of Liptov, the local inhabitants' Slovak nickname according to the book, ${ }^{26}$ are easily trumped in the reader's mind by the involved descriptions of Simplicissimus's experiences with the brigands of Šariš and Zemplín counties. That passage in particular contains motifs and images of brigandage further developed in literary and folk narratives in the $18^{\text {th }}$ and $19^{\text {th }}$ centuries. It is probable that The Hungarian Simplicissimus not only absorbed some of these images from the local culture, but passed them on. Immediately popular, the book was reissued twice within a year of its release. It became an available source of motifs for subsequent writing about brigands.

The fate of the nickname "Bad Birds," a marginal curiosity in brigand-themed narratives, offers a brief example of how other, complex motifs were not only recorded, but also potentially transmitted across time by the book. ${ }^{27}$ The nickname appears to be unknown in contemporary Slovakia, nor does it appear in folk songs or high literature about brigands. ${ }^{28}$ Yet references to this nickname occurred as recently as in the early $20^{\text {th }}$ century. One reference appears in a fictionalized travelogue about the Tatras, the highest mountain ranges of the Carpathians straddling the Slovak-Polish border. ${ }^{29}$ The author may have actually come across it in the Polish Podhale region, as he says, but

${ }^{25}$ Stanisław Szczotka, Materiały do Dziejów Zbójnictwa Góralskiego z lat 1589-1782 (Lublin - Łódź: Polskie Towarzystwo Ludoznawcze, 1952).

${ }^{26}$ He says that the inhabitants of Liptov (the Slovak spelling is employed in the book) are called Liptace, but nicknamed Zliptace: "von den Zliptaken [...] gedencken; dieses Wort Zliptak heist Deutsch ein schlimmer oder böser Vogel dann Zli heißt böß und Ptak heißt ein Vogel und im plurali numero heissen böse oder schlimme Vögel Zliptace” Ungarischer Oder Dacianischer Simplicissimus... 145.

${ }^{27}$ Links of five of the potential literary motifs to the $19^{\text {th }}$ century are in Goszczyńska, Mit Janosika... The explication is insignificantly at variance with the German original.

${ }^{28}$ The conclusion is based on my random interviews in Slovakia, including in Liptov County, in June-July 2004, and on internet searches for related words and phrases in Polish and Slovak, which yielded no current usage.

${ }^{29}$ The author says that shepherds from Liptov would take terrible revenge on Polish Górals and they, in turn, called the people from Liptov "Bad Birds": "Liptáci mstili se góralům strašně, tak že ti jim přezdívali "źly [sic] ptacy (zlí ptáci).'” Karel Drož, Život na Tatrách (V Praze [Prague]: V komisi Fr. Rivnáče, 1906): 192. 


\section{Martin Votruba: Hang Him High: The Elevation of Jánošik to an Ethnic Icon}

given his use of some unattributed sources throughout the book, his "Bad Birds" may have been lifted from The Hungarian Simplicissimus, which was reissued in the middle of the $19^{\text {th }}$ century, ${ }^{30}$ or from another account that drew on it. A book that relied even more heavily on a variety of unattributed sources may have done the same in the 1930s. ${ }^{31}$ Whether they were passed on by The Hungarian Simplicissimus or maintained by popular culture, the motifs written down in the second half of the $17^{\text {th }}$ century have come a long way.

Chapter 17 of The Hungarian Simplicissimus describes, with a lot of hyperbole, the capture of the wandering student Simplicissimus. He is brought to the brigand leaders Beyhus, Hafran, and Janko, ${ }^{32}$ whose surname of Pacholek the narrator explains as "the Bold Guy." 33 Students like Simplicissimus were among the frequent travelers on the roads of Europe, and so among those more likely to be the victims of ambushes. Unlike merchants, students traveled with few possessions. They may have therefore offered less resistance, and hence suffered fewer consequences. Moreover, their verbal skills were bound to be good, on average, so the proverbial poor students were likely tellers of such tall stories, occasionally based on their experiences but mostly fictional, both for entertainment and for money. Although the narrator of The Hungarian Simplicissimus is a student, the motif of students' encounters with brigands need not have stemmed only from a literary source like this one. It, too, may already have been present in and transmitted through the local folklore.

The chapter also contains the nascent motifs of testing the captive's skills, although it is merely his capacity to play the trumpet, a remote echo of a literal reading of the Latin dictum cantabit vacuus coram latrone viator circulating all over Europe, ${ }^{34}$ and the motif of giving to the poor, but what is at issue here is remuneration for his playing. With the captive's competence and with the brigands' satisfaction, we get another motif

${ }^{30}$ Ungarischer Oder Dacianischer Simplicissimus... edited by Johann Christian Seiz (Leipzig: O. Wigand, 1854).

${ }^{31}$ Frant[išek]. Václav Peřinka, Veselé putovanie po Slovensku, kniha l'udového humoru a vtipu (V Prahe [Prague]: Vyd. Orbis, 1929). (It was reprinted in 1934.)

${ }^{32}$ He says these brigands were Rusyns: "ich sagte Windisch und halb Rusnakisch weil sie alle diese Rauber Rusnaken" Ungarischer Oder Dacianischer Simplicissimus... 182. The modern Rusyn spelling of their names could be Баюз, Гавран, and Янко Пахолок оr Пахолек.

${ }^{33}$ The narrator says that the surname is related to the word "boy/guy": "vom Janko einem Pacholek [...] das ist einem tapffern Kerl" and "ich werde Pacholce das ist auf Deutsch Kerl." He also explains plausibly $\mathrm{Ha}$ fran as "raven" (although that would be a Slovak, that is, West Slavic version of the word, while the contemporary standaridzation of Rusyn has East Slavic roots). Ungarischer Oder Dacianischer Simplicissimus... 195, 182. The name Beyhus, also spelled Beyhuß in the book, is probably from the Hungarian $b a-$ jusz, "whiskers," which entered the Carpathian Slavic and Germanic vernaculars.

${ }^{34}$ Literally, "the empty-handed traveler will sing vis-à-vis a brigand," but its contextual meaning was "a person who has nothing has nothing to lose or fear," which would have been more characteristic of students than of merchants and other travelers. It was probably first written down around 100 C.E. in satire "X Omnibus in terris...," Decimus Junius Juvenalis, Saturae, ed. Ulrich Knoche (München [Munich], 1950): verse 22. - There are several wordings of the saying, always with latro, "brigand." 
when they reward him with lengths of cloth. Although cloth may appear an unlikely reward today, it was among the brigands' prized possessions and was needed to repair their clothing, which was more prone to wear and tear, yet less readily replaceable in case of damage than the clothes of law-abiding subjects. ${ }^{35}$ Rolls of cloth, not readymade clothes, were loaded in merchants' wagons. Cloth was also among the more durable goods in their loot, but not as easy to exchange as money, jewelry, or guns, so the brigands were likely to have a surplus of cloth in their hiding places. ${ }^{36}$ The narrative has the poor student benefiting from the encounter in the end, which shows Janko Pacholek as potentially benevolent and generous - Jánošik's typical feature in the $19^{\text {th }}$ century. Yet, The Hungarian Simplicissimus is far from painting the brigands as admirable characters. In fact, a compelling moral lesson and motif appears in the next chapter when Simplicissimus observes the execution of the three brigands in the town of Prešov.

In The Hungarian Simplicissimus, we get a Central European literary treatment of the brigand image that matches the folk songs, and that is well over a century earlier than the commencement of its noble, pre-Romantic makeover. The continuance of those motifs was doubtless helped by their inclusion in this popular book, but they were also probably maintained through the local oral narratives about brigands. Such vacillation between engrossing images of the wild, apparently carefree life of brigands, on the one hand, and accounts of their capture with judgmental undertones, on the other hand, was still typical a hundred years later, when Jánošík began to emerge in folk songs and literary texts.

\section{Ethnic identification}

Although Slovak brigand-themed folk songs were recorded much later, the few specific historical references in them point to the $17^{\text {th }}$ and $18^{\text {th }}$ centuries. In those rare instances when the brigands' adversaries, the police or authorities, are identified ethnically, the reference is to the Germans. The $17^{\text {th }}$ and $18^{\text {th }}$ centuries were the period when the Habsburgs forcibly endeavored to integrate the Kingdom of Hungary into their empire, which involved bringing in German troops and administrators. The Habsburgs' Germans, not the Kingdom's pockets of old German settlements in Spiš County and elsewhere, came to be seen as the enemy of the multi-ethnic Kingdom. Those two centuries, when the pressure from Vienna was forceful and mostly exercised by ethnic Germans, were the only period when references to the Germans could have entered Slovak folk songs as synonymous with the authorities. Before that, the local authorities

${ }^{35}$ John S. Koliopoulos, Brigands with a Cause, Brigandage and Irredentism in Modern Greece 1821-1912 (Oxford: Clarendon Press, 1987).

${ }^{36}$ Jozef Kočiš, Neznámy Jánošík (Martin: Vydavatel'stvo Osveta, 1986) creates a weighty narrative about Jánošík's apparent revolutionary intentions from a historical report that guns and substantial amounts of cloth were discovered in some of his hiding places. 
stemmed from the local population (Slovak, Hungarian, German, other). After the $18^{\text {th }}$ century, the Kingdom's administration was gradually Hungarianized.

Contrary to the assumptions engendered by the modern image of Jánošík, the old images of brigandage do not contain references to an ethnic clash between Slovaks and Hungarians. The rare, fleeting references to the Germans create inconsistent images of a patriotic clash between the subjects of the Kingdom and alien intruders, but not of a Slovak-German ethnic clash, nor of a clash between Slovak subjects and German landowners. Nor are any ethnic tensions implied in the proceedings from the trial of the actual historical figure Juraj Jánošik. With the exception of a German officer's wife, who was ambushed while merely passing through Liptov County, Jánošik's victims were not identified ethnically. Most of them were commoners, two were noblemen and two were priests. Since Jánošik's band operated in the predominantly Slovak counties, it can be reasonably assumed that the majority of the victims were Slovaks.

\section{Folk songs}

For at least a century, this brigand's name remained just one among those who came to be featured in literature. Most of the brigands in folk songs are nameless, or are called Janík, Janíčko, Jano, Janko, derivations of Ján (John), the generic male name in folk songs and narratives regardless of their theme. These names are reminiscent of Jánošík's name phonetically. Moreover, the real brigand's family name originated as a Slovak derivation of János, the Hungarian equivalent of "John," with the same suffix -ik that occurs in Janik (and in the names of nine of the brigands that came up during Jánošik's interrogation). Hungarian was one of the languages current in the Kingdom, and the speakers in the Carpathian region recognized the parity between Ján and János. Once the circumstances arose, the phonetic similarity and semantic equivalency of the name Jánošik with the generic male name of folk songs and tales made it easier for Jánošík's image to gain frequency as a generic image of a brigand.

Although some folk songs with brigand themes contain the motif of the payback to the oppressive overlords, most are not far from The Hungarian Simplicissimus in their treatment of highway robbery. Characteristically, that happens to be the case with a motif in the oldest recorded Slovak folk song about a brigand. Some lines from this song were hand-written in a religious song book from $1490 .{ }^{37}$ It is still alive today. ${ }^{38}$ Rather than a celebration, one of its versions is a wagoner's defiant accusation of a brigand who robbed him. Quite contrary to the image of the brigand as a noble defender against the overlords, which was enshrined in high culture in the $19^{\text {th }}$ century, this old folk

37 “Vlha, vlha, pekný vták," in Jozef Minárik, ed. Slovenská renesančná lutna, Antológia zo slovenskej renesančnej poézie, (Bratislava: Tatran, 1982): 378; and Viera Gašparíková, ed. Jánošík, obraz zbojníka v národnej kultúre (Bratislava, Tatran, 1988): 129.

38 "Ide furman dolinou..." Available online at http://supermusic.sk/skupina.php?action=piesen\&idpiesne $=4070$. 
song actually likens the brigand's conduct to that of the masters (pán) and its another version recorded in the 1830s describes how the wagoners got together, overpowered the brigands and handed them over to the police. ${ }^{39}$ An old Polish rhymed folk legend about Jánošik traceable to the early $19^{\text {th }}$ or perhaps late $18^{\text {th }}$ century goes even further when it ends with the hint of harmony with an overlord. ${ }^{40}$ Jánošík barges in on a count's home and parties with him at his expense, but turns down the treasures the frightened count brings. Instead of robbing him, Jánošík tells him he is a good nobleman and says his good-byes.

Throughout the $18^{\text {th }}$ century, the few depictions of brigands preserved in high literature from the Slovak counties paint them as little other than "merry criminals." The oldest of these depictions is a Latin Brigand Song in a handwritten volume from 1762.41 A brigand chief urges students to abandon college and join him. He promises them the rule of the new, "joyous" law. What it is to secure, though, is not universal freedom from oppression, but plentiful booty for the brigands themselves. Like The Hungarian Simplicissimus and folk songs, and like subsequent works from the period, the end of the poem introduces the moral issue. 'There are lots of thieves,' the poem sums up the brigands' understanding of their place in society, 'so let's just make sure that it is not us who will be hanged high in the town of Nitra.'

\section{First mentions of Jánošík}

When Jánošik entered the literary scene in the $18^{\text {th }}$ century, his image was no different from that of any other brigand. He was neither praised, nor was he a central brigand figure. A journal in 1785 published "An Excellent Sermon by a Certain Preacher in the Days of the Chief Brigand Jánošik." 42 It mentions the brigand's name only in its title. The quasi-sermon is bookended by a rudimentary story of a priest captured by brigands in the Tatra mountains of Liptov County. In his lecture to them, he points to similarities between their lives and that of Jesus Christ, only to turn their expectations around and condemn them in the end. A similar, but unpublished, short, rhymed Polish sermon

39 "Ide furman dolinami..." Manuscript by Rehor Pauliny, Zborník Rehora Paulinyho (Poltár: [manuscript], 1830-1832), Archív literatúry a umenia Slovenskej národnej knižnice, Martin: MJ 446. Reprinted in Jozef Minárik, ed., Po chodníčkoch kamenných po cestičkách krvavých alebo Piesne a verše o živote, láske a smrti urazených, ponižených a nevolných, ale aj nepokorených, hrdých a proti krivde sa búriacich slovenských dedov, pradedov a prapradedov, ktorí veky trpeli na panských dvoroch, bojiskách a šibeniciach. Výber slovenskej rukopisnej sociálnej poézie (1577-1870) (Bratislava: Tatran, 1980): 325-326.

${ }^{40}$ Anon., "Jak Janosik tańcył z hrabinom," in Teresa Komorowska and Viera Gašparíková, eds. Zbójnicki dar, Polskie i słowackie opowiadania tatrzańskie, (Warszawa [Warsaw]: Ludowa Spółdzielnia Wydawnicza, 1976): 29-30.

${ }^{41}$ István Szakolczai, "Praedonum cantus" (1762). Published as “Zbojnícka pieseň,” in Jozef Minárik, trans. and ed., Z klenotnice staršieho slovenského písomníctva 3: Antológia barokových literárnych textov I (Poézia), (Bratislava: Tatran, 1989): 171-172.

${ }^{42}$ Anon., “Znamenitá kázeň gednoho Kazatele za dnu hlawnjho zbognjka Jánošjka,” Staré nowiny liternjho uměnj, May 1785: 65-68. 
with a less contentious ending was conceived in the $17^{\text {th }}$ century. ${ }^{43}$ It spread in handwritten copies. A rustic reduction of the anecdote was still surviving as a folk narrative in the Polish Tatras by the end of the $19^{\text {th }}$ century. ${ }^{44}$ The two old literary versions appear to have been inspired by a brief paragraph (98 words) about a priest and soldiers in church ${ }^{45}$ from a Latin collection of anecdotes and witticisms circulating all over Europe and republished among other places in Bratislava in 1770.46 If they were, the Polish and Slovak texts dispensed with the ironic put-downs that crop up throughout the Latin anecdote and thus delivered a more surprising punch line. The general motif of a clergyman preaching to his brigand captors in the mountains was not a transposition of the soldiers from this $17^{\text {th }}$-century source, however. That motif dates back to at least the $4^{\text {th }}$ century when it appeared in a Latin-written account of how Bishop Martin of Tours mended the ways of a brigand whose band ambushed him in the Alps. ${ }^{47}$ The story was in public awareness, since passages from St. Martin's Life were recounted annually in churches on his feast day. It boosted his cult in the Kingdom that he was born in Sabaria, now Szombathely in Hungary.

While the switch from a priest decrying raucous soldiers on his own ground to a priest condemning his captors in the mountains could make the central character of the Slovak narrative appear foolhardy, "An Excellent Sermon" continues the motif from St. Martin's Life. It validates the priest's action by portraying the brigands as receptive. Numerous brigand stories recorded later repeat the sermon motif and bring in modifications, which improve the image of the brigands. An Excellent Sermon contains barely a hint of this when it brings up, perhaps ironically, the possibility of a reward. ${ }^{48}$ In the

${ }^{43}$ Wacław z Potoka Potocki (†1696), "Kazanie do zbojcow [sic],” in Aleksander Brückner, ed. Ogrod [sic] fraszek, vol. 2, (We Lwowie [Львів, Lviv]: Nakładem Towarzystwa dla Popierania Nauki Polskiej, 1907): 238-239.

${ }^{44}$ It was published by Andrzej Stopka, "Chapter X." Sabała: Portret, Życiorys, Bajki, Powiastki, Piosnki [sic], Melodye.(Kraków: L. Zwoliński i Spółka, 1897): 64-66; as a tall tale narrated by a real-life colorful Góral shepherd, brigand, and storyteller Jan Krzeptowski-Sabała (1809-1894).

${ }^{45}$ The anecdote was first suggested as a source of the Polish text by Julian Krzyżanowski, "Kazanie zbójnickie." Głos Narodu 39, no. 351-352, 1932: 4; the same anecdote was then suggested as a source of the Slovak text by Rudo Brtán̆, "Prvý l'udový motív o Jánošíkovi z roku 1785," Elán 10, no. 1-2, Sept.-Oct. 1939, pp. 5-6. Brtáň was aware of Krzyżanowski's comments, which were republished in a more accessible volume in 1935 (Julian Krzyżanowski, Paralele: studia porównawcze z pogranicza literatury i folkloru. Warszawa: Nakł. Towarzystwa Literackiego im. A. Mickiewicza, 1935).

${ }^{46}$ Anon. [other editions attributed to J.-P. Langius, i.e., Johann Peter Lange], "Milites cui sunt similes," DEMOCRITUS RIDENS. SIVE CAMPUS RECREATIONUM HONESTARUM CUT EXORCISMO MELANCHOLIE [sic] (Presburg [sic] [Bratislava]: Sumptibus Joann Doll Bibliopole, MDCCLXX): 206. - Not to be confused with the like-named English series, this volume was first published in Amsterdam in 1649 and republished at various times and locations; it got as far as Russia in the $18^{\text {th }}$ century, translated as Демокретус смеющийся.

${ }^{47}$ Written around 400 C.E. by Sulpicius Severus, “Chapter 5." Vita Sancti Martini Episcopi et Confessoris. Available at www.thelatinlibrary.com/sulpiciusseverusmartin.html. English translation (microfilm) by Mary Caroline Watt, St. Martin of Tours the chronicles of Sulpicius Severus done into English from the French of Paul Monceaux and with an introduction by him (London: Sands \& Co., 1928).

48 "Gakowau offeru tento Kazatel za swau horliwau kázeň obdržel, nenj známo.” (What alms the Preacher received for his passionate sermon is not known.) Anon., "Znamenitá kázeň...” p. 68. 
earlier Polish version, the priest actually receives small change. As a result of ongoing revisions, the brigand will take control over the sermon away from the priest. Jánošik, who will become an ex-student, will compel his captives to deliver a sermon as a test of the quality of their education, and will reward them although he has not benefited from their capture in any material, or moral way.

\section{Market songs}

The most influential texts with brigand themes circulating in the $18^{\text {th }}$ century subsequently proved to be market songs. ${ }^{49}$ Although they are not known to have appeared in print then, hand-written volumes were a common medium among the educated through the $19^{\text {th }}$ century. Texts, both handwritten and printed, that caught a reader's interest, were commonly copied and thus became available to new circles of readers.

The content of the preserved brigand market songs, their spread in the $19^{\text {th }}$ century, as well as their junction with high literature show them to be the closest early domestic ancestors of the modern myth of Jánošík. Combining multitudes of often loosely connected and sometimes contradictory motifs, they swing from fascination with crime, quick money making, and indulgence to the gallows and just punishment. These songs, given voice by presenters at markets, must have left lasting impressions in their listeners' minds especially given the scarcity of visual entertainment.

Only one of the four preserved brigand market songs from the $18^{\text {th }}$ century is about Jánošik. ${ }^{50}$ An initial impetus that helped to maintain his name in local memory was the hunt for Jánošik's accomplices that followed his execution. The courts asked captured brigands whether they had had contact with him. The emerging currency of the name Jánošik linked to the theme of brigandage was reinforced within nine months by yet another execution of a Jánošík when Juraj's brother Ján was sentenced for highway robbery. ${ }^{51}$ It is indicative of the generic nature of the early images of Jánošik that they contain no implication of whether they represent one or the other of the brothers, or even an acknowledgement that there were two brigands called Jánošík. Early images did not give him a first name and a surname, but simply the semi-generic Jánošík. In his modern myth within high culture, there are no images of Juraj Jánošík's siblings, nor is there any current popular awareness that he had a brigand brother.

In the market song about Jánošík, three of the specific references identify his captors ethnically as the German (not Hungarian) police, place his character in Liptov County (as in "An Excellent Sermon"), and have him hide his booty in the Tatras. These

${ }^{49}$ Jan Vilikovský, "Trři nejstarší slovenské zbojnické písně,” Bratislava IX, 1935, 550-570; and Jan Nehýbl, "Kramářská píseň o Ondrášovi," Slezský sborník, Acta silesiaca 48, no. 8, 1950: 484-485. (There are several reprints of the songs.)

${ }^{50}$ The songs may have first been written down around 1780, or even earlier. The other three songs are about Surovec, about Adam and Ilčík, and about Ondráš.

${ }^{51}$ Kočiš, Neznámy... 86; Sroka, Janosik... 41. 


\section{Martin Votruba: Hang Him High: The Elevation of Jánošík to an Ethnic Icon}

craggy mountains in north-central Slovakia and southern Poland, also referenced in The Hungarian Simplicissimus (as "Snow Mountains"), became highly symbolic in Slovak culture in the $19^{\text {th }}$ century, partly through mutual reinforcement with Jánošik's myth. They were first described as lying in the Slovaks' area of residence in a treatise on the Kingdom's history in 1734.52 More profoundly than Jánošik's image, the mythology of the Tatras had a divergent development in Slovak and Polish cultures. ${ }^{53}$ In Slovakia until the present, the Tatras have functioned as a symbol of the country, of its heartland, or as a means of defining its territory in symbolic geography as extending "from the Tatras to the Danube" in a manner more consequential than, but comparable to the American "from sea to shining sea." In the market song, though, the name was probably still only referential, and possibly connoted wild, inaccessible places.

Just to illustrate the nature of the brigand market songs and how far they are from the modern image of Jánošík, one segment in it notes that Jánošik's capture is the consequence of his crimes, then mitigates this claim by asserting that he did not kill many people and that he robbed the masters. The song then describes him actually robbing farmers, and expresses a regret that he was betrayed by his comrade, because otherwise he could have been the emperor's soldier. All of this within merely thirteen verses of a market song that is sixteen-times longer. ${ }^{54}$

Another indirect indication of the popularity of brigand themes in folk culture is that by the beginning of the $19^{\text {th }}$ century they began to appear in publications aimed at a wide audience. A calendar for $1807,{ }^{55}$ published by Juraj Palkovič, poet and professor of Slovak at the Lutheran junior college in Bratislava, ${ }^{56}$ carried four verses about brigands in each of the first four months. An alumnus of the University of Jena, Palkovic had taken a history course from Schiller, the author of The Robbers, while a student there. Palkovič had already published verses with images of "strong men" (shepherds, not brigands) who lived in the mountains for months at a time. ${ }^{57}$ One of the brigands that cropped up in the calendar was Jánošik. He and another brigand, Vlček, are mentioned in the four verses of the February section. These verses summarize how Jánošík

${ }^{52}$ Samuel Timon, Imago nova Hungaria, reprasentans regna, provincias, Banatus, \& Comitatus ditionis Hungarica (Cassoviæ [Košice]: Typis academicis Soc. Jesu, per J. H. Frauenheim, 1734). (There are several reeditions and partial translations.)

${ }^{53}$ Patrice M. Dabrowski, “'Discovering' the Galician Borderlands: The Case of the Eastern Carpathians," Slavic Review 64, no. 2 (Summer 2005): 381-402.

${ }^{54}$ Anon., "Píseň o Jánošíkovi zbojníkovi," verses 162-174, in Vilikovský, “Třri nejstarší...” (There are several reprints of the song.)

${ }^{55}$ Giřj Palkovič [also spelled Juraj/Gur/Georg Palkowitsch/Palkovics], Wětssj a zwlásstněgssj Nowý y Starý Kalendár na rok Páně 1807 ([s.1.]: Pjsmem Ssimona Petra Webera, 1806).

${ }^{56}$ In the calendar and on other occasions, Palkovič identified himself as Professor of the Slovak Language, but his position was also advertised as that of the Czechoslovak language, partly in order to help secure funds from Czech-speaking sponsors in the neighboring Margraviate of Moravia and Kingdom of Bohemia.

${ }^{57}$ Giřj Palkovič, Muza ze slowenských hor. Swazeček priwnj (We Wacově [Vác]: W Antonjna Gottljba, 1801). (There are several reeditions of the individual poems.) 
robbed travelers and gave students cloth, and describe him, Vlček, and their comrades as cutthroats. As to other motifs, the phrase that Jánošík measured cloth "from beech to beech," 58 that is to say generously, appeared here in print for the first time. Doubtless, the phrase already existed in conversational Slovak, but when printed in connection with Jánošik, it marked a step towards highlighting his generosity. This phrase soon became a hallmark of stories and poems about Jánošik, and it has since developed into a common Slovak idiom with the meaning shifted to "measure or do in a careless manner."

Within two years, Jánošík again appeared in print. The volume Slovak Poets II included, with some modifications, two of the market songs from the $18^{\text {th }}$ century, one of them about Jánošík. ${ }^{59}$ This collection was edited by Bohuslav Tablic, a pastor, poet and scholar, who, like Palkovič, had studied with Professor Schiller. In Tablic's volume, the market song was accompanied by a brief account of Jánošik's documented trial and postulated biography that included mentions of the sermon motif, of his generosity to his captives (he measured cloth "from beech to beech") as well as to a nobleman, and of a tradition according to which he used to be a good student of the humanities. ${ }^{60}$ No historical evidence suggests a learned Jánošík, but Tablic's published information about this tradition brought him closer to his later Romantic image of a rebel versed in his cause. A key factor revealed by Tablic's gist of Jánošik's trial was that he was not charged with killing any of his victims. The manner of Janošik's execution highlighted by Tablic became another recurrent motif in literature: the court ordered that a hook be threaded through his left side and that he be hung by it, not an unusual punishment for brigand leaders in the Carpathian region. But the chief momentum that came from Jánošik's first mini biography was that a wider, intellectually-inclined audience learned from a regarded source that a young, reputably beneficent and perhaps erudite Slovak brigand was sentenced to death around the time their grandparents were born even though he was definitely not a murderer. It was likely that sooner or later, some of that information would find resonance among the burgeoning social and ethnic activists. The preceding and following decades in European history were rife with thoughts about the relationship between the rulers and the ruled, with discussions of rebellions and revolutions, and with efforts to develop inspirational, ethnically defined areal histories and heroes. At the same time, although Prof. Schiller had died in 1805, graduates from

\footnotetext{
${ }^{58}$ Beech, covering about $30 \%$ of Slovakia's forested land, is the country's most common tree concentrated in the inhabited mountain valleys at and above $1,800 \mathrm{ft}$, followed closely by spruce (27\%), which is more typical of the less populated higher elevations. Martin Moravčík, Forest in Slovakia 2005. Zvolen: Lesnícky výskumný ústav, 2005.

${ }^{59}$ Bohuslaw Tablic [also spelled Bohuslav], Slowensstj Werssowcy. Collecta revirescunt. Swazek druhý (We Wacově [Vác]: v Antonjna Gotljba prywil. kněhtlačitele, 1809): 120-137. (There are several reprints.)

${ }^{60}$ Bohuslaw Tablic, a 3-page unnumbered footnote to "Jánossjk Liptowský Laupežnjk," in Tablic, Slowensstj Werssowcy... 120-123.
} 
the universities in Saxony continued to return to the Slovak counties with direct experience of fervent German ethnic myth making.

\section{The first elevation}

A literary juncture of folk and high culture only five years later opened up the image of a brigand, who came to be called Jánošik with increasing frequency, to later Romantic and anti-establishmentarian interpretations. The publication of a book of poetry entitled Muse of the Tatras with a Slavic Lyre by 18-year-old Pavol Jozef Šafárik in 1814,61 a year before he went to study at Jena, brought into Slovak literature a handling of the brigand theme that was in line with its development in German literature, not with the multifaceted domestic traditions. Rather than Schiller's robber, Šafárik's brigands more closely resembled Classicist heroes fused with the idyllic depictions of shepherds typical of the Enlightenment. Added was a sprinkling of domestic motifs, which Šafárik knew better than someone who merely grew up in the local culture from his own collection of folk songs. For instance, as the readers were probably beginning to expect, Šafárik's Classicist brigands, too, give students cloth measured from beech to beech. A conspicuous example of the functioning equivalency between the generic male name in folklore Ján (John) and the apparently specific name Jánošik, was that Šafárik used Ján as coreferential with Jánošik in one instance, although the brigand's given name was Juraj (George). ${ }^{62} \mathrm{~A}$ new, ethnic motif appeared, too. The major poem featuring brigands in the collection says it is a celebration of pacholci ("young, often brash guys," from pacholek, the nickname of the friendly ${ }^{63}$ brigand chief Janko in The Hungarian Simplicissimus) described as "Slavic" - Slawenj Slowanských pacholkü, in the original spelling.

Regardless of the blend of style and motifs, the novelty in Saafarik's image of the brigands was the suppression of the criminal aspect, especially in the segments that featured Jánošík, and the overall level of ennoblement. Šafárik's brigands have freeflowing, long, curly blond hair blown by the wind rather than the contemporary farmers' tight, well greased and tied hairstyles. Quite unlike the villagers' weathered faces, the brigands' complexions are pale "like a lily." They dance, drink, and eat; "connected in various joyful alliances," they "chase lads, chase girls," "rob... lure, and make merry." The new, ethnic motif is repeated. Jánošík is the glory of the Slavs. ${ }^{64}$

${ }^{61}$ Anon. [Pavol Jozef Šafárik], "Slawenj Slowanských pacholků," and "Poslednj noc,” Tatranská Můza s ljrau Slowanskau (W Lewoči [Levoča]: v Jozefa Mayera kněhtlačitele, 1814): 25-39, 46-54. (There are several reeditions and reprints.)

${ }^{62}$ Šafárik, verse 78, "Slawenj Slowanských pacholků," in Tatranská Můza... 28.

${ }^{63}$ Unlike Jánošík's inherent friendliness to the captives in the $19^{\text {th }}$ century literature, his predecessor's friendliness in the $17^{\text {th }}$ century source was motivated: Janko Pacholek felt a special kinship with Simplicissimus because the student spent time at the town of Sabinov where he knew Janko's philandering girlfriend.

${ }^{64}$ Such pan-Slavic generalizations of Jánošík took root and have shown up sporadically in popular awareness in the West Slavic cultures into the present. Rather than attribute Jánošík to the local Polish or Carpathian culture, a Polish blogger recently wrote that "Janosik was kind-of Slavic Robin Hood" (Janosik był takim 
Derivations of the words Slav and hero occur throughout, but no heroic acts, which would have to have been highway robberies. The author, who was to become Imperial and Royal censor for a decade of his life, skirts around, not just the criminal, but also the rebellious images of highway robbery present in some folk songs. Robbing is glossed over. Emphasis is instead placed on giving charitably to the poor and especially on the romance of freedom, on the brigands' carefree life in the mountains. Occasional lyricizations of the brigands' area of residence go back several centuries in European writing, ${ }^{65}$ but unlike the idealized worlds of shepherds in Classicist pastorals, they did not appear in literature from the Slovak counties. One of the early semi-pastoral images linked to the Slovak mountains in print was Ode to Mt. Sinec by Palkovič. ${ }^{66}$ It contained no images of brigands, only of "strong men" (shepherds) up on the mountain, but because it was dedicated to that specific mountain near the author's birthplace, intentionally or not, it was also an ode to a mountain that, on the other side, rises above the village where Jánošik was captured. With Šafárik for the first time, the geographically elevated territory of much of Slovakia's forested outdoors begins to take on the character of a mythical realm of fun-filled, festive, capriciously free living elevated figuratively above the overlords and out of their reach. This new image of the brigands' joyful refuge is, however, also painted as an image of the past. Muse of the Tatras contains a reference to Mt. Sinec, and two lines in it copy rhymes from Palkovič's ode in order to ask "where have all the 'strong men,' the heroes of the mountains gone." In one verse, Šafárik contrasted his brigands' lofty world of days gone by with "our" trying life.

When the merrymaking is brought to an end and Jánošik is captured, Šafárik laments it as a betrayal. He abolished the judgmental twist on the parallel between Jánošík and Christ from "An Excellent Sermon" and drew the comparison further. After Jánošík is mocked, tortured and condemned, his hanging is depicted as elevating him "towards the bright heaven." 67 The brigands will always be praised, we are told. It would become common to give the number of the band members under Jánošik's guidance as the, clearly, apostolic twelve and even make one of them his traitor.

Šafárik's subsequent distinguished career as the scholar whose works became the source of information for German academe about the history and culture of the Slavs in

słowiańskim Robin Hoodem). Małgorzata Musierowicz, "Placek zbójecki Janosika," 23 August 2001, at http://serwisy.gazeta.pl/edukacja/1,51819,408775.html.

${ }^{65}$ Perhaps the earliest one, 'the wood of Belregard,' appeared in 1304-1307 in four verses of the AngloNorman poem usually called "The Outlaw's Song" written by an unknown author. - Gillian Spraggs, Outlaws \& Highwaymen: The Cult of the Robber in England from the Middle Ages to the Nineteenth Century (London: Pimlico, 2001). The poem is available online at www.outlawsandhighwaymen.com/trail.htm.

${ }^{66}$ Palkovič, "Oda na horu Synec," Muza... 28-29.

${ }^{67}$ Slovak and some other Slavic languages commonly use the same word for both heaven and sky: nebo. While the original meaning of the venerable phrase hang him high (hóð/hongeð him héh/héah) in AngloSaxon English was "crucify him," there is no evidence of a Slovak traditional phrase for "execute by hanging” with a similar history - Šafárik's intended connotation must have been "ascension." 
the Habsburg monarchy 68 drew attention and added weight to his early poetry and its depiction of Jánošík for decades to come. Yet, Šafárik was not the founder of the contemporary image of the brigand. In-between his depictions of the brigands as semiclassical heroes acting out folk motifs in a pastoral setting, he intermittently berates Jánošik's comrades not merely for not standing by him in his time of need, but also for their crimes. The poet's voice tells them that robbery is not honorable, that it means living in fear and leads to punishment. The judgmental motif of the earlier handling of the brigand theme in Slovak culture showed up, although it cannot be attributed unequivocally to domestic influence. Schiller's play The Robbers, for instance, ends on a similar note. But from among almost two dozen brigands Šafárik's poem names and upbraids, Jánošík comes off clean.

Although intertwined, these two contradictory themes are not equal. The imagery and length of the exultant passages dominate, while the rebukes appear more as afterthoughts. It cannot have been difficult for the readers to find inspiration only in the poems' blissful, free world with Jánošik and the brigands as its heroes. In the end, this interpretation prevailed in high culture. During the following three decades, brigand themes and Jánošik occurred with increasing frequency in written literature. They picked up on the traditional domestic motifs, reduced the judgmental motif, and expanded the imagery of carefree ease, freedom, and their association with the mountains.

\section{Final transition}

The decade from the mid-1830s to the mid-1840s was a watershed in Jánošík's transition from low road to high culture. It witnessed a shift from the last occurrences of the judgmental motif to the early entrenchment of Jánošik's intellectualized image as it appears in contemporary Slovak high culture. At its beginning, pastor, ethnic activist, major poet and influential academic Ján Kollár, a graduate of Jena after Schiller's death, published his extensive collection of folk songs. ${ }^{69}$ Kollár saw the brigands as criminals, and therefore watched the growing commonness of brigand themes in publications with apprehension. For him, they were characters to be condemned, not cherished. His

${ }^{68}$ Paul Joseph Schaffarik, Geschichte der slawischen Sprache und Literatur nach allen Mundarten (Ofen [Budapest]: Mit kön. ung. Universitäts Schriften, 1826); his History of the Slavic Language and Literature in All the Vernaculars was the first, and for a long time the only voluminous academic work in German on the topic. Safárik published several other influential works.

${ }^{69}$ An impetus for Kollár's collection came in 1817 from the German Romantic author Johann Wolfgang von Goethe who asked Kollár for samples of Slovak folk songs during Kollár's stay in Jena. Goethe metrified and published some of them. - Jan Kollár [also spelled Ján], ed. Národnié zpiewanky čili pjsnè swětské Slowáků w Uhrách gak pospolitého lidu tak $i$ wyššjch stawi̊, sebrané od mnohých, w pořádek uwedené, wysvětlenjmi opatrené. Djl perwý. Wydánj hogně rozmnožené i perwé dwa tištěné swazečky w sobě obsahugjcj (W Budjně [Budapest]: W král. universické tiskárně, 1834); and Jan Kollár, ed. Národnié zpiewanky... Djl druhý... (W Budjně [Budapest], 1835). (There are several reeditions, reprints and adaptations.) 
stance emanated not only from his explication of Christianity, but additionally from Johann Gottfried Herder's guiding view of the Slavs as historically peaceful. ${ }^{70}$ Brigandage, then, was clearly at odds with one of Kollár's goals, namely to restore the Slavs to their original state. Although the wording was not instrumental, it is worth noting that among other things, Herder literally said that the Slavs used to be "enemies of robbery [des Raubens] and plunder" and that their present regretful state was the result of centuries of subjugation by "Christian masters and robbers [Räuber]," that is, in the two instances when he referred to the Slavs' nemeses, Herder used the German words whose common, though not exclusive Slovak equivalents at the time were and partly still are "brigandage; highwayman, brigand" (zboj, zbojník).

Kollár did not just preach against brigandage, postulate it as alien to the Slavs and list it specifically among his examples of transgressions against the eighth commandment. ${ }^{71}$ In the monumental expanded version of The Daughter of Sláva published a few years earlier, Kollár actually reserved two sonnets to place not nameless, generic brigands, but specifically Jánošík and his comrades in hell. ${ }^{72}$ That differentiated choice also attested to the continuing confluence of the generic image of a brigand with the molded image of Jánošík. Kollár's judgment showed in his collection of folk songs, too. Among the well over 2,400 songs he chose for the public to read, less than one-third of one percent concerned brigand themes (one of them with Jánošik, "a swift lad," described as capable of defending himself against up to twelve brigands who are getting drunk and ready to thrash him). ${ }^{73}$ Had he concurred with popular demand, he would have been able to include more. He was the last eminent author to censure brigands in high litera-

${ }^{70}$ Johann Gottfried Herder, "Slawische Völker," Ideen zur Philosophie der Geschichte der Menschheit, Part 4, vol. XVI, 4 (Riga und Leipzig: J. F. Hartknoch, 1791). (There are numerous reeditions and translations.) Available online at http://www.textlog.de/5663.html.

${ }^{71}$ As a colorful interposition, but also as a bow to the local lore, he actually invoked the Slovak proverbial brigands' command in one sermon: "Give your soul to God and ducats to us!" (Daj Bohu dušu a nám dukáty!), a parallel of the English "Stand and deliver!" Jan Kollár, "W den Petra Pawla a w neděli ssestau po S. Trogici (1822) I," and "Neděle gedenáctá po S. Trogici," Nedělnj, swátečné i přjležitostné Kázně a Řeči (W Pessti [Budapest]: tiskem Trattera a Karoliho, 1831): 497-511 and 280-294.

72 Jan Kollár, sonnets 572-573 of the Fifth Cantos “Acheron," Sláwy dcera, Lyricko-epická báseň w pěti zpěwjch. Úpelné wydánj (W Pešti [Budapest]: tiskem Trattera a Károliho, 1832). (There are numerous reeditions, reprints and translations, some with an altered numbering of the sonnets; the original edition is not paginated.) Kollár's major inspiration for The Daughter of Sláva was Dante Alighieri's (Divine) Comedy from 1308, which uses two verses to place the brigands Rinier da Corneto and Rinier Pazzo in the $7^{\text {th }}$ circle of hell (“Inferno, Cantos XII," verses 137-138); by contrast to Jánošík’s reputation, they were known to Dante, although not referenced so in the Comedy, as murderers of a bishop (Julia Bolton Holloway, "Chancery and Comedy: Brunetto Latini and Dante." Lectura Dantis 3: 73-94).

${ }^{73}$ Song “49. Jánošjk," in Ján Kollár, Národnié zpiewanky čili pjsně swětské Slowákůw w Uhrách gak pospolitého lidu tak $i$ wyššjch stawůw [...] Djl druhy. Wydánj hogně rozmnožené i peršé dwa tištěné swazečky w sobě obsahugjcj. (W Budjně [Budapest]: W Král. universické tiskárně, 1835): 37. 


\section{Martin Votruba: Hang Him High: The Elevation of Jánošík to an Ethnic Icon}

ture, and the only one to censor their extant images out of a presumably representative cross-section of folk songs. ${ }^{74}$

Kollar was doubtlessly reacting to the cumulation and amplification of references to brigands and Jánošík in folk as well as in high culture. Yet, poetic evidence suggests that he was not quite innocent of spreading Jánošík's fame, either. In the very sonnet that places Jánošík in hell, the Daughter of Sláva, the title character, modeled initially on Kollár's college love, reminds her interlocutor-author that he used to tell her stories about the "gallant stickup man." 75 References to brigands appeared among stories and cultural accounts of the Carpathian region published locally in German, one of them with amplified versions of what had appeared in Slovak Poets II and with a range of other brigand motifs attached to Jánošík, from the details of his clothes to his encounters with students. ${ }^{76}$ A widely-read Slovak calendar featured an extensive digest of Jánošík's trial proceedings. ${ }^{77}$ A published and performed play included a brigand scene and song. ${ }^{78}$ And given his academic disposition, Kollár, future professor of archeology at the University of Vienna, could not then but add to knowledge about Jánošík by compiling the first, inevitably minuscule, bibliography of the publications about him. ${ }^{79}$

Kollar's was the last major effort to stem the flood. By the time he was 53 , a decade after he had all but excluded brigands from his collection of songs, three young authors, lower nobleman Štefan Marko Daxner (23), ${ }^{80}$ Samo Chalupka (34), ${ }^{81}$ and Ján

${ }^{74}$ Kollár also had an incidental personal motivation for his dislike of brigandage: according to his posthumously published memoir, he grew up with stories of how his maternal ancestors had been assaulted by brigands, and he treasured one of the thaler coins, presumably stained with his ancestors' blood, that they had saved during the fight. Ján Kollár, Pamäti z mladších rokov života (Liptovský Mikuláš: Vydalo vydavatel'stvo Tranoscius, a.s., 1997): 9.

${ }^{75}$ The character is called Mína, Kollár called his love Vilma Fridriška, Slovak versions of Wilhelmina Friderika, in his correspondence (Jozef Ambruš, ed. Listy Jána Kollára I, 1816-1839. Martin: Matica slovenská, 1991.). She was baptized Johanne Auguste Friederike Schmidt (Jan-Christoph Hauschild, Die Kleine Welt des Alltags und das Universum der Zahlen: Ludwig Kunze, eine soziale Biographie. Darmstadt: Verlag Jürgen Häuser, 1990) and used Friderika in Kollár's circles in Budapest and Vienna (archives, Slovenská národná knižnica) after she was finally able to marry him in 1835 . Her brother was Wilhelm, so Wilhelmine/Wilhelmina (Minne/Minna) that gave Mína could have ben one of the names recurrent in the family and used as Friederike's nickname.

76 Johann Csaplovics [also spelled Ján/János Čaplovič], "Räuber,” Gemälde von Ungern [sic] (Pesth [Budapest]: C. A. Hartleben, 1829): 268-271; and Alois von Mednyanszky [also spelled Aloyz/Alajos Mednyánszky], Erzählungen, Sagen und Legenden aus Ungarns Vorzeit. 2 Theile (Pesth [Budapest]: K. A. Hartleben, 1829). (There are several reeissues and translations.) - The story by Mednyanszky is that of a robbernobleman's family. Csaplovics was a lower nobleman, Mednyanszky was a baron.

${ }^{77}$ Kasspar Fejérpataký de Kelecsén [also spelled Gašpar Fejérpataky-Belopotocký], "O zbogstwj Gura Jánossjka, gináče Jánossjaka řečeného, rodilého z Ťarchoweg zbognjků a laupežnjků hlawnjka (hadnád’a),” Nowý y Starý Wlastenský Kalendář na rok Páně 1832 (W Lewoči [Levoča]: Pjsmem Jana Werthmüllera, [s.a.]). Fejérpataky was a lower nobleman.

${ }^{78}$ Ján Chalupka, Kocaurkowo, anebo Gen abychom w hanbě nezůstali: Weselá hra we 3 gednánjch (Lewoča [Levoča]: [s.n.], 1830). (There are several reeditions and adaptations.)

${ }^{79}$ Jan Kollár, Wýklad čili Přjmětky a Wyswětliwky ku Sláwy Dceře s obrazy, s mappau a s Přjdawkem drobněgšjch básnj rozličného obsahu (W Pešti [Budapest]: tiskem Trattnera a Károliho, 1832): 453.

80 Štefan Marko Daxner, “Poklad Jánošíkou,” Orol Tatránski 1, no. 6 (1845): 1-2. 
Botto $(17)^{82}$ each wrote a poem about a brigand. ${ }^{83}$ These three Romantic works, published in quick succession from 1845 to 1846 (one in a hand-written student journal), crafted the first clear-cut images of the brigand as a benevolent, rebellious, tragic, quasi-folkloric freedom-fighter, and called him Jánošik. The poems augmented the perception of folk legacy by imitating the verse structures of folk songs, which became a canon of Slovak Romantic poetry. The authors brought together the two developmental lines of the brigand theme. On the one hand, they picked up on the guiltless elevation of Jánošik first played up in Slovak high culture by Šafárik, mixing in the panEuropean attributes of a Romantic hero. On the other hand, they encased Jánošík entirely in traditional domestic motifs, but with the fundamental deletion of the judgmental motif. Historical circumstances opened up brigandage to extensive mythologizing, too, by removing the reality check. The brigand was quickly becoming a historical character. In an illustrative example, Liptovský Mikuláš, the place of Jánošík's hanging, watched its last execution of a brigand, Matej Tatarka, in 1829.84 The following year it saw a premiere of a play with a cheerful brigand scene and song. ${ }^{85}$ The brigands' mountain world had been extensively undermined by the modern state. ${ }^{86}$ Two decades after their literary debuts, the two poems about Jánošik by Chalupka and Daxner, and two additional ones by Chalupka with nameless brigands but isomorphic motifs became the first four brigand-themed entries in the school literature reader. ${ }^{87}$

Since this elevation happened in the period of mounting ethnic activism in Central Europe, Jánošík could not become merely a Romantic hero. The Slovak literary and social discourse highlighted his ethnicity, which then appeared in implicit contrast with

${ }^{81}$ Samo Chalupka, “Jánošíkova náumka,” Orol Tatránski 2, no. 35 (1846): 273-274. It was later revised by the author and published under the titles "Jánošíkova pamiatka," and "Likavský väzeň."

82 JMskí [Ján Botto, AKA Janko Maginhradskí], “Pjeseň Jánošíkova,” Holubica, Zábavník Levočskích Slovákou. Ročník I, Číslo V. Sv. I. 24 Listopada, 1846/47: columns 68-71 [the issues are not paginated but the columns are numbered throughout the volume - effectively, the poem is on pages 1-2 in volume 1, issue 5 of 24 Nov. 1846]; Facsimile: Holubica, levočský rukopisný zábavník s prílohou Sokol. Martin: Matica slovenská, 1977. There are numerous reissues both in the original and principally reworked and expanded as "Smrt' Jánošíka," then revised and renamed "Smrt' Jánošíkova."

${ }^{83}$ All three were Lutherans, Daxner became a lawyer, Chalupka was a pastor, and Botto became a civil engineer, but none of them went to study in Germany. Daxner was Kollár's parishioner in Budapest when he published this poem. Samo Chalupka's older brother was Ján Chalupka, the author of the play Kocaurkowo...

${ }^{84}$ Tatarka was sentenced and executed on 20 and 22 October 1829. Slavko Churý, "Zbojníctvo v Liptove v prvej polovici 19. storočia," Vlastivedný sborník Považia 8, 1966: 26-35.

${ }^{85}$ The amateur troupe Diwadlo slowanské swato-mikulášske premiered Ján Chalupka’s Kocaurkowo... on 22 August 1830. The county seat was called "Saint Nicholas" in the Kingdom's languages then.

${ }^{86}$ This was noted in Greece with similar geographic conditions, Koliopoulos, Brigands...

${ }^{87}$ S[amo]. Chalupka and pseud. Samo, "Na Královej Holi," "Jánošíkova pamiatka," "Junák;” and Š[tefan]. Daxner, "Poklad Jánošíkov," in: Emil Černý, ed. Slovenská čítanka. Pre nižšie gymnasia (Vo Viedni [Vienna]: Tlač Karola Goríška, 1864): 57-58, 257-259, 281-282; and 323-325. (A version of "Na Královej Holi" is known as "Král’ovohol’ská." "Jánošíkova pamiatka" was first published as "Jánošíkova náumka," and later revised as "Likavský väzeň.”) 
the ethnicity of the now politically overpowering Hungarians. Jánošík's Romantic elevation projected into the distant past the current ordained linguistic and ethnic Hungarianization of the Slovaks, Germans, Romanians, and other groups in the Kingdom. Throughout the preceding 800 years, the overlords in the Slovak counties were an unidentified mixture of ethnicities, including Slovak, German, and Hungarian. The language of administration and education was Latin until the $19^{\text {th }}$ century, while Slovak, German, Hungarian, and other vernaculars of the Kingdom were used freely in other spheres of life.

Under the impact of the abrasive ethnic activism of the $19^{\text {th }}$ century, however, the new Jánošík was construed as both a Romantic rebel against the oppressive feudal overlords, who stood symbolically for the current political inequalities under the Habsburgs, and as a Slovak rebel against the projected ethnic oppression by the overlords of the past, who were now reinterpreted as ethnically Hungarian by both Slovak, and Hungarian high cultures. When Jánošik was molded into a tragically rebellious image of a brigand in the mid-19th century, the authors drew on many of the motifs developed in local high literature and folk songs, but discarded entirely the recurrent judgmental motif. It would be easier to call this a fully new development in literature from the Slovak counties, if it were not for the Legend of Saints Zoerardus and Benedict from the $11^{\text {th }}$ century. Contrary to the legend's handling of one of the cutthroats, the Romantics did not dare to save Jánošík from the gallows, but just as Bishop Maurus reinvented another brigand, the young, antiestablishmentarian poets bridged 700 centuries and made Jánošík a hallowed man. 